\title{
BMJ Global Health The international and domestic politics of type 2 diabetes policy reform in Brazil
}

\author{
Eduardo J Gómez
}

To cite: Gómez EJ.

The international and domestic politics of type 2 diabetes policy reform in Brazil. BMJ Global Health 2020;5:e002457. doi:10.1136/ bmjgh-2020-002457

Handling editor Seye Abimbola

Received 10 March 2020

Revised 14 May 2020

Accepted 18 May 2020

\section{Check for updates}

(c) Author(s) (or their employer(s)) 2020. Re-use permitted under CC BY-NC. No commercial re-use. See rights and permissions. Published by BMJ.

College of Health, Lehigh University, Bethlehem, Pennsylvania, USA

Correspondence to Dr Eduardo J Gómez; edg219@lehigh.edu

\section{ABSTRACT}

Introduction Understanding the international and domestic political factors influencing the evolution of type 2 diabetes policies and primary care institutions is a new area of scholarly research. This article contributes to this area of inquiry by illustrating how a government's shifting foreign policy aspirations, that is, to establish the government's reputation as an internationally recognised leader in type 2 diabetes policy ${ }_{2}$ and presidential electora incentives provide alternative insights into the evolution of type 2 diabetes treatment policies and primary care institutional reforms.

Methods I conduct a single-case study analysis with the usage of qualitative data; quantitative statistical data on epidemiological trends and government policy spending is also provided as supportive evidence.

Results The case of Brazil illustrates how a reduction in foreign policy commitment to international reputation building in health as well as presidential electoral incentives to use diabetes policy as an electoral strategy account for a decline in sustaining policy and primary care institutional innovations in response to type 2 diabetes. Conclusion Future scholars interested in understanding the lack of sustainability and effectiveness in type 2 diabetes programmes should consider investigating the complex international and domestic political factors influencing political interests, incentives and commitment to reform.

\section{INTRODUCTION}

In the recent years, the prevalence of type 2 diabetes has burgeoned in Brazil, due to several risk factors, such as overweight and obesity, genetic predispositions and race. ${ }^{1}$ According to recent estimates, there are currently 13 million individuals with type 2 diabetes, making Brazil the fourth largest nation in the world in disease prevalencefalling only behind the USA, India and China. ${ }^{2}$ From 2006 to 2017, data from the Ministry of Health (MoH) national survey system, VIGITEL, noted a $54 \%$ increase in diabetic cases for men and $28 \%$ for women. ${ }^{3}$ From 2006 to 2016, there was a $60 \%$ increase in type 2 diabetic cases throughout the

\section{Key questions}

What is already known?

- Several challenges have emerged with the implementation of type 2 diabetes treatment programmes and primary care reforms in Brazil.

- While several innovative treatment and self-care management programmes have been introduced, recent presidential administrations have not followed through with previous government commitments to the universal distribution of diabetic medication and supportive primary care innovations.

What are the new findings?

- This study reveals that a combination of international and domestic political factors provide alternative insights into why these policy challenges have occurred in Brazil.

- Findings suggest that the Brazilian government's eventual change in foreign policy aspirations to no longer seek to build its reputation as an internationally recognised leader in diabetes policy can lead to a reduction in sustaining previous policy innovations. This outcome has also emerged due to recent governments' lack of interest in using diabetic treatment policy as an important presidential electoral strategy.

- Addressing these complex international and domestic political factors provides an alternative and much needed approach to explaining the political actors, interests and incentives to reform in response to worsening type 2 diabetic conditions.

What do the new findings imply?

- These findings suggest that public health researchers concerned with the effective implementation of type 2 diabetes treatment programmes need to simultaneously address the political factors and motivations influencing the entire policy implementation and agenda-setting process.

- Moreover, understanding challenging economic and/ or health systems contexts is insufficient for addressing ongoing gaps in policy implementation.

country. ${ }^{4}$ Overall costs to the healthcare system is expected to double by 2030 , reaching approximately US $\$ 97$ billion. ${ }^{4}$ Within Brazil, most diabetic cases are located in the more economically affluent southern region, with 
the city of Rio de Janeiro having the largest number of cases, estimated at 10.4 cases per 1000 inhabitants. ${ }^{2}$ In large part, this disease has emerged due to several years of economic growth and global integration: specifically, a sudden influx of imported foods via international trade, access to cheaper foods, changes in family lifestyles, increased sedentary activity, and a general increase in weight gain and obesity. ${ }^{1}$

Nevertheless, little is known about the complex international and domestic political factors driving the reform and evolution of type 2 diabetes policy in Brazil. Furthermore, we know little about how a sudden change in a government's foreign policy objectives and political context can gradually undermine previous policy innovations. Thus, the key research question driving this study is the following: why and how do international and domestic political factors matter in explaining Brazil's success, as well as its recent limitations, in pursuing two policy outcomes of concern: universal access to diabetic medication and primary care innovations in the provision of treatment and diabetes self-care management (DSM) services? And what new policy lessons can be learnt? I address these questions through a careful analysis of the case of Brazil, while beginning my study with a review of what is already known in the type 2 diabetes policy literature.

In addressing these questions, this article claims that while Brazil's MoH succeeded in increasing universal access to type 2 diabetic medication and pursuing innovative institutional primary care reforms, over time these efforts were not matched with the financial and infrastructural support needed to sustain and deepen these reform efforts. Eventually, this change in policy priorities and outcomes was attributed to a shift in the government's foreign policy goals as well as a lack of presidential electoral incentives to improve type 2 diabetes policy.

Indeed, beginning under the Luiz Inácio 'Lula' de Silva (2002-2010) and Dilma Rousseff (2010-2016) presidential administrations, a combination of foreign policy aspirations, that is, establishing the government's reputation as an internationally recognised leader in type 2 diabetes policy, and presidential electoral incentives to campaign on diabetes policy, medical costs and their association with poverty, generated incentives to ensure universal access to medicine and innovative primary care reforms. At a theoretical level, then, the case of Brazil highlights how a government's foreign policy aspirations can successfully merge with domestic electoral incentives to inspire type 2 diabetes policy reform.

Nevertheless, Brazil's recent transition to a more geopolitically isolated and conservative government under the Michael Temer (2016-2018) and Jair Bolsonaro (2018-present) presidential administrations have failed to provide the resources needed to sustain Lula and Rousseff's policy reforms-notwithstanding worsening diabetes prevalence and healthcare outcomes. Therefore, a key lesson that emerges from the case of Brazil is that, with respect to chronic diseases requiring ongoing government interventions and support (such as DSM), achievements in securing universal access to medication and institutional primary care reforms are meaningless unless governments sustain and deepen their political commitment to prioritising these endeavours.

\section{METHODS}

When conducting research, this article employed qualitative research methods. A single-case study analysis of Brazil was conducted for several reasons: first, to critically evaluate the existing literature on type 2 diabetes policy, ${ }^{5-9}$ as well as the more recent literature discussing the politics of diabetes policy reform. ${ }^{10-12}$. Specifically, I reviewed and critically analysed the health systems and policy literature focusing on type 2 diabetes, with respect to prevention and self-care management. Second, through this analysis, my objective was to discover and propose an alternative analytical approach, one which stresses the merger of foreign policy and domestic electoral politics. Indeed, my alternative analytical approach combines the global health diplomacy literature emphasising the strategic usage of domestic health policy innovations as a means to increase the government's international reputation in global health policy and influence ${ }^{13}$ with the literature emphasising the domestic politics of health policy reform as a strategy for electoral gain. ${ }^{14}{ }^{15}$ As emphasised by Gayard, ${ }^{16}$ Gómez $^{13}$ and Feldbaum and Michaud, ${ }^{17}$ theories in global health diplomacy and foreign policy explain how a government's interest in building their international reputation in health (e.g., 'soft power'), such as having strong public health programmes with global policy influence and commitment to meeting heathcare needs, can incentivise leaders to pursue new institutional and policy innovations and areas of technical expertise. My alternative analytical approach, therefore, addresses the health systems and diabetes policy literature's reluctance to thoroughly consider the international and domestic politics of type 2 diabetes policy making.

My third objective is to provide an in-depth empirical qualitative case study analysis, which focuses on documenting specific actors, interests and policy actions. As Gerring ${ }^{18}$ maintains, all of these efforts, as well as others (eg, establishing hypotheses and discovering casual mechanisms), underscores the benefits of conducting small-N case study analysis. Finally, the case of Brazil was selected because it has one of the highest prevalence rates of type 2 diabetes in Latin America, because of my extensive field work experience in Brazil, knowledge of its healthcare system and ability to read the Portuguese language.

With respect to data, several qualitative documents, such as journal articles, media articles and policy reports, were used in order to provide empirical factual evidence. These data sources were obtained in the English and Portuguese languages. The method that I used for finding this qualitative data was through the usage of an on-line search engine, Google Scholar, by finding 
additional references from the bibliographies of the initial qualitative documents found in this web-based search, and by asking colleagues in Brazil that specialise in type 2 diabetes policy for recommended publications. Quantitative data on the prevalence of type 2 diabetes were obtained from international health organisations, such as WHO, while data on government spending on diabetes programmes was obtained from policy reports in Brazil. The research for this project began in October 2018 and concluded in February 2020.

\section{Patient and public involvement}

In this study, my research questions and outcomes were not informed by patients' priorities, experiences and preferences. Instead, my questions and outcomes were driven by political science theoretical and policy issues regarding the international and domestic political factors influencing type 2 diabetes policy. Moreover, patients were not involved in the design of this study, nor will my results be disseminated to them. Additionally, because this research conducted a qualitative document review, there was no need to undergo a standard ethical review process.

\section{RESULTS}

The politics of institutional change and type 2 diabetes policy

The challenge to create and implement type 2 diabetes treatment and self-care management programmes has inspired a considerable amount of scholarly attention. In addition to studies focusing on the implementation of national diabetes prevention programmes, ${ }^{56} 19$ researchers have focused on the design and implementation of treatment policies, such as providing medication in a timely basis, helping patients improve nutritional habits, while avoiding out-of-pocket expenses for medication. ${ }^{20-22}$ At the primary care level, others have examined pilot programmes providing educational materials, counselling, while ensuring periodic blood glucose testing. ${ }^{720} 23$

With respect to the provision of treatment services, researchers have focused on health systems capacity, such as the availability of local government financial resources (for providing tests and medications), human resources, for example, the availability of primary care staff, and infrastructure (eg, purchasing laboratory equipment) ${ }^{7-9}{ }^{20}$ Others have instead emphasised the importance of primary care physician training, experience and willingness to provide these treatment services. ${ }^{20} 24$ Finally, also problematic are patients' geographic and infrastructural barriers to accessing treatment and medication services, such as the lack of access to reliable transportation and poor road conditions.

Different from these treatment programmes, DSM programmes require ongoing healthcare provider efforts to monitor and work with patients on managing their particular type of diabetes. ${ }^{20} 232526$ With respect to those studies focused on DSM programmes, research has primarily targeted issues such as the design of healthcare systems, access to primary care services, ${ }^{5} 2728$ and the availability of primary care workers and infrastructure for providing assistance. ${ }^{820} 29$ Others instead focus on the presence of effective primary healthcare teams and their efforts to work with patients, families and community members in providing DSM services. 672030 Alternatively, research has emphasised the role of supportive family members, volunteer community groups, nongovernmental organisations (NGOs) and activist networks for providing ongoing DSM support. ${ }^{203132}$ Finally, others have highlighted the importance of reducing inequalities in access to effective DSM services-particular between urban and rural areas, the reasons why these inequalities persist and what can be done to overcome them. ${ }^{8} 292$

However, this article is less interested in the design of healthcare systems, technical and human resource capacity in providing treatment and self-care management services. Instead, it explores a neglected area of research, that is, providing a political science perspective for better understanding the international and domestic sources of successful institutional and policy reform in the area of type 2 diabetes policy, a neglected area of research, ${ }^{121320}$ and the political conditions that can eventually undermine this successful process.

For the most part, research focusing on the politics of diabetes programmes has primarily focused on agendasetting process by exploring the role of the international community, specifically international health agencies and advocacy networks, in motivating governments to prioritise spending for prevention and treatment services. ${ }^{10} 1120$ Other political scientists have examined the difficulties that public health bureaucrats have in garnering sufficient legislative attention and support for type 2 diabetes programmes. ${ }^{12}{ }^{20}$ In contrast, this article focuses on the politics of the entire policy-making process ${ }^{33}$ by first focusing on policy implementation of pre-existing type 2 diabetes policies, followed by circling back to the agendasetting process, that is, seeing a decline in diabetic policy agenda-setting prioritisation following a subsequent decline in the government's foreign policy aspirations and electoral policy interests.

In so doing, this article submits an alternative perspective to account for policy and institutional change processes in the area of type 2 diabetes policy. Instead of focusing on political processes within governments, such as 'change actors' seeking to discredit existing policies, build supportive coalitions within government and civil society to transform and/or replace them, ${ }^{34}$ this article finds that it is a combination of foreign policy and domestic electoral factors that account for shifts in government support for policies designed to provide effective diabetes treatment and self-care management services. More specifically, the case of Brazil suggests that, in a context of increased global integration, where nations, particularly the emerging economies (eg, BRICS), are eager to improve their international recognition and influence in global health policy, ${ }^{13}$ other influential 
factors are perhaps more important. That is, a government's foreign policy aspirations in striving to establish its reputation as internationally-recognised leaders in type 2 diabetes policy, and an interest in making type 2 diabetes policy a prominent national electoral issue, are equally if not more important factors leading to successful policy and institutional change. With respect to foreign policy aspirations, the government establishes its reputation as an internationally recognised leader in diabetes policy by marketing its success at regional and international conferences, while sharing policy experiences and providing recommendations to help other countries improve their policy response. In the absence of foreign policy aspirations and electoral policy interests, and as the case of Brazil illustrates, governments will have little interest in sustaining and strengthening type 2 diabetes treatment and self-care management programmes.

Indeed, recent research by Gómez ${ }^{13}$ has shown how a nation's geopolitical aspirations to increase their international health policy reputation and influence though domestic policy reforms leads to significant improvements in government responses to NCDs. Similarly, a host of studies have demonstrated how politicians' interests in using health policy as an important national electoral issue and selling point during electoral campaigns compels politicians to pursue progressive health policy reforms. ${ }^{14} 1535$ Combining the geopolitics of health with shifting political elite electoral policy incentives may provide a more persuasive account for why governments pursue type 2 diabetes policy reforms, and how the absence of these international and domestic political factors contributes to a lack of reform sustainability and an eventual decline in type 2 diabetes policy prioritisation. In sum, I found that the aforementioned literature was silent on addressing these domestic and international political factors influencing diabetes policy reform.

\section{Innovations in type $\mathbf{2}$ diabetes policy reform in Brazil}

By the turn to the 21st century, Brazil's government did a commendable job of responding to type 2 diabetes. In addition to creating several obesity prevention, diabetes and NCD programmes focused on providing increased nutritional awareness, the MoH Family Health Programme (FHP) also worked with families to provide treatment and DSM services. ${ }^{13}$ Composed of a team of doctors, nurses and community healthcare workers, the FHP was instrumental in educating diabetic patients and families about how to treat and manage diabetes. In addition to providing treatment, such as insulin shots and medications, by the early-2000s FHP teams also provided guidance on nutrition and physical exercise to families, teachers and healthcare workers in schools. ${ }^{13}$

In 2004, the Lula administration (2002-2010) also worked with the $\mathrm{MoH}$ to create a partnership with the state governments to ensure universal access to low cost essential medicines for type 2 diabetes and other NCDs. This programme was called the Farmacia Popular (Popular Pharmacy) programme. In 2006, the programme was expanded to include all private pharmacies and drug stores and was renamed the Aque tem Farmacia Popular (Popular Pharmacy is Available Here) programme. ${ }^{36}$ Through this programme, the government began to subsidise $90 \%$ of the reference price for medication used to treat diseases such as diabetes, hypertension, asthma, rhinitis, Parkinson's, osteoporosis and glaucoma. ${ }^{36}$ Furthermore, in 2007, a federal law was enacted guaranteeing the universal distribution of diabetic medication and the testing equipment needed to measure blood sugar levels. ${ }^{37}$ Promulgated through a federal law, beginning in 2010, all patients with type 2 diabetes were able to receive their insulin and oral medication free of charge at SUS network pharmacies. Nevertheless, access to this medication was restricted to those registered through the SUS primary care system. ${ }^{37}$

The subsequent Dilma Rouseff presidential administration (2010-2016) expanded on these efforts by creating the Saúde Não Tem Preço (Health has No Price) initiative. This endeavour took further steps to expanded access to type 2 diabetic medication. ${ }^{38}$ Through this programme, those pharmacies enrolled in the Aque tem Farmacia Popular programme began to offer free medicine to all in need, regardless of whether or not patients were registered through SUS. According to Bertoldi et $a l,{ }^{39}$ through this initiative, the government increased its distribution of medicines by $70 \%$.

When it came to providing type 2 DSM services, a key primary care institutional innovation emerged with the $2008 \mathrm{MoH}$ programme titled Nucleo de Apoio na Saúde (NSF, Nucleus of Health Support). Realising that the FHP was becoming increasingly limited in the number of medical staff available to provide these services to families, the NSF provided an auxiliary team of specialists, composed of nutritionists, psychologists and physical fitness experts, to provide follow-up family home care visits with patients assigned to a FHP team. ${ }^{37}$ In essence, the FHP's new work on diabetic self-care management, when combined with the Nucleo de Apoio auxiliary teams, provided a successful case of what Gómez ${ }^{40}$ refers to as a primary care institutional conversion process: that is, instead of creating a new federal agency responsible for providing these services (and thus avoiding more government costs), the MoH repurposed the FHP's responsibilities by assigning new policy tasks and additional manpower in the area of diabetic treatment and self-care management.

Under the Lula and Rousseff administrations, other federal programmes were created that facilitated the provision of type 2 diabetic treatment and self-care management services. In a context where many of Brazil's rural poor lacked access to SUS primary care centres, in 2013, the MoH created the Mais Médicos (More Doctors) Programme. Through this programme, the $\mathrm{MoH}$ provided new incentives for SUS primary care providers to work in rural areas through the provision of additional financial benefits; moreover, a key aspect of this programme was hiring primary care physicians 
from Cuba to work in remote areas. ${ }^{41}$ This programme, therefore, served to further ensure that type 2 diabetics in Brazil's most remote areas received care.

\section{The international and domestic politics of reform}

But what were the political factors driving the government's improved policy response to type 2 diabetes? Two factors were important. First, Brazil's government built on its long-held tradition of striving to bolster its reputation as an internationally-recognised leader in public health policy by pursuing stronger domestic policy reforms while also helping other nations strengthen their policy response to diabetes. It is important to keep in mind that the government had already established this foreign policy objective when it came to HIV/AIDS under the Lula administration ${ }^{13}$; it did the same again when it came to type 2 diabetes. Under Dilma, the $\mathrm{MoH}$ frequently attend regional health conferences in Latin America in order to display the government's aforementioned policy innovations, policy ideas, recommendations, as well as the Dilma administration's commitment to helping other Latin American countries respond to diabetes. ${ }^{42}$ By sharing policy experiences and helping neighbouring countries, Dilma helped to increase the government's international policy reputation and credibility.

In addition, following a similar strategy that was seen under the Lula administration, Dilma strategically used international institutions to market her government's policy success. In 2011, she attended a UN general assembly in New York to not only describe the success of her diabetes programme with respect to patients benefiting from these programmes, but also her political commitment to providing diabetic medication for the poor. ${ }^{39}$ The $\mathrm{MoH}$ also increased its participation in major global health events, such as the World Diabetes Day. ${ }^{39}$ While Dilma was not as proactive at the international level as her predecessor Lula with Dilma focusing mainly on domestic economic recovery, she nevertheless maintained Lula's tradition of marketing Brazil's success and commitment to universal healthcare and poverty reduction at the international level.

The success of the aforementioned policy initiatives, as well as Lula and Dilma's international marketing of their programmes, began to pay-off, as their policies began to receive international recognition and support. In 2015, an in depth evaluation of the Farmácia Popular, Aqui tem Farmácia Popular and Saúde Não tem Preço programmes was conducted, revealing an increase in the number of facilities throughout the nation dispensing diabetic (and other) medications, a burgeoning increase in the number of diabetic users and beneficiaries for these programmes, and a reduction in reference prices for medications. ${ }^{43}$ What's more, in 2008, WHO wrote an article highlighting the success of Brazil's FHP and its ability to locate and provide treatment to previously ignored diabetics. ${ }^{44}$ Other research and policy evaluations have underscored the success of the FHP in providing diabetic services, increasing patient access and satisfaction with services, increased patient adherence to medications, increased physical activity and improved diets. ${ }^{45}$ The aforementioned primary care programme, Mais Medicos, was also praised by WHO for its successful scientific evaluations and results, revealing an increase in population coverage in the first level of primary care, increased medical consultations, high quality services, and impact in the poorest regions. ${ }^{47}$

In 2011, at an international summit held in the state of Bahia, Brazil, organised by the World Diabetes Foundation, the Assistant Director General for the WHO, Ala Alwan, praised Brazil's Minister of Health for 'working to ensure that the response to diabetes is placed at the forefront of national and global efforts to improve health and to support sustainable development'. ${ }^{42}$ Moreover, in September 2016, the PAHO Director, Carissa F. Etienne, claimed that Brazil's aforementioned Mais Medicos programme was 'an example of successful international technical cooperation' between Brazil and $\mathrm{Cuba} ;{ }^{48}$ the PAHO report which mentioned Etienne's comment also noted not only the program's success but that it also provides primary care diabetic services. ${ }^{48}$ Etienne went on to comment that it is not surprising that the Mais Medicos programme has captured the interest of other countries in the Region'. ${ }^{48}$ That same year in 2016, WHO wrote articles highlighting Brazil's commitment to investing in diabetes programmes, with its emphasis on dietary improvement, exercise, early detection and the universal provision of medication for all diabetics. ${ }^{49}$ The success of Brazil's federal programmes eventually led WHO to work with Brazil in implementing its diabetes prevention, early detection and self-care management services. ${ }^{49}$

Nevertheless, electoral politics also mattered. The Dilma administration was the first in Brazil to use the urgency of responding to the country's type 2 diabetes situation, and other NCDs, as an important campaign issue for re-election. In addition, Dilma ensured access to diabetic medicine in all pharmacies and at lower prices. ${ }^{50}$ Moreover, Dilma dovetailed the right to insulin with her commitment to ending poverty, especially as out-ofpocket expenses for insulin and other related medications were increasing throughout the country, in turn contributing to poverty among low-income type 2 diabetics. During her re-election campaign season in 2013, Dilma also attended the opening ceremony of a major insulin producing factory in the state of Belo Horizonte, Biom, which signalled her commitment to ensuring universal access to insulin. ${ }^{51}$ Through these public statements and policy commitments, Dilma believed that the aforementioned institutional and policy initiatives would help to secure her PT's (Partido dos Trabalhadores, ie, Worker's Party) broad-base political support and her re-election in 2014.

Furthermore, it is important to note that this was a time of increasing social and political unrest. By 2013, several mass public demonstrations arose in major cities, such as São Paulo and Rio, in response to the government's 
inadequate provision of social services, which included public transportation, reliable road infrastructure and quality healthcare. Furthermore, due to a worsening economic recession, the Dilma administration began to freeze social welfare spending, notwithstanding vehement criticisms from civil society regarding ongoing high taxation and inadequate healthcare services. General federal funding for SUS, for example, did not increase during her watch. ${ }^{52}$ This situation contributed to a sudden change in political context.

\section{Political transition and the disincentives for reform}

Indeed, society's increased frustration with the Dilma administration eventually facilitated the political opposition's ability to force her out office. In 2015, the conservative political opposition, led by Senator Michael Temer of the Brazilian Democratic Movement (PMDB) political party, succeeded in impeaching Dilma due to her alleged mishandling of public funds. Temer was sworn in as interim president from 2011 to 2016. For many, Temer's election signalled the re-emergence of the old conservative political elite, that is, individuals that were present during the transition to democracy in the late-1980s and believed in fiscal stability and political conservatism.

It was under this new political climate that several of the previously mentioned type 2 diabetes treatment and selfcare management programmes began to suffer. Federal funding for most of the aforementioned programmes started do decline, as did presidential and congressional support. ${ }^{40}{ }^{53}$ In fact, shortly after entering office, Temer sought to withdraw the availability of insulin through the Aque Tem Farmácia programme,${ }^{54}$ with the rational being that prices for insulin were still too high. By 2017, and as figure 1 illustrates, those individuals receiving medication benefits from Aque Tem Farmácia began to decrease. What's more, federal funding for the Farmácia Popular programme began to decline under Temer, in turn further underscoring his administration's lack of commitment to type 2 diabetic treatment and care-see figure 2.

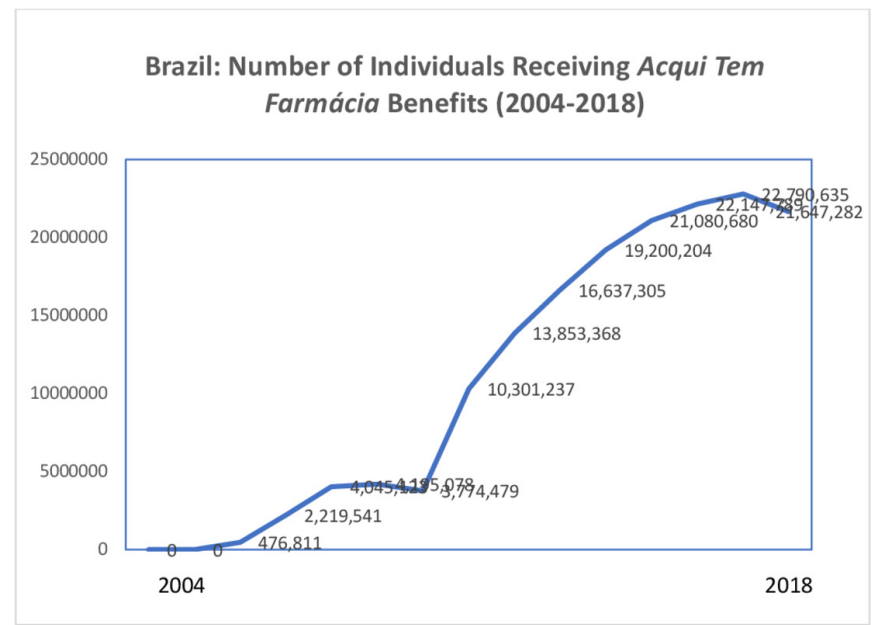

Figure 1 Brazil: Number of Individuals Receiving Acqui Tem Farmácia Popular Benefits; Source: Junqueira. ${ }^{58}$

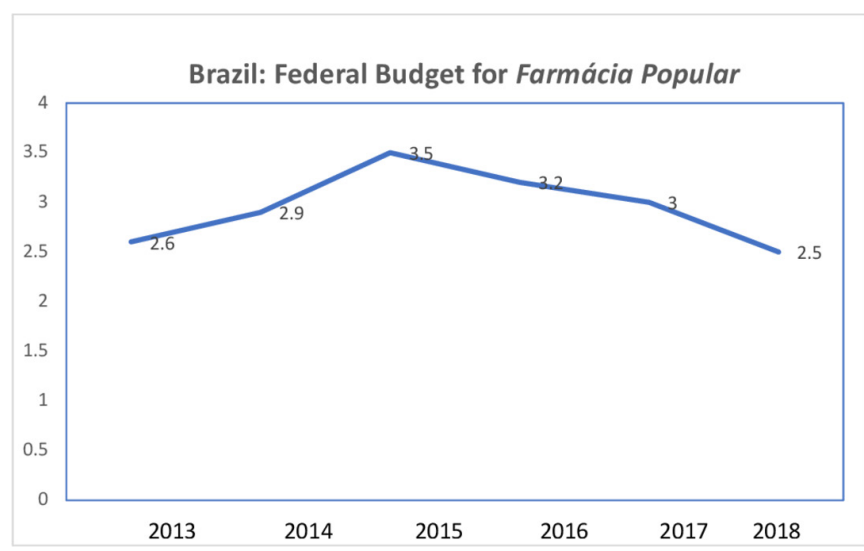

Figure 2 Federal Budget for Farmácia Popular. Source: Junqueira. ${ }^{58}$

This situation worsened with the arrival of the conservative Jair Bolsonaro administration on 1 January 2019. During this time, the $\mathrm{MoH}$ had requested an increase in funding for the Farmácia Popular programme and community healthcare workers; Bolsonaro eventually rejected their proposal. $^{55}$ In response, the congress rejected Bolsonaro's decision, claiming that more funding was needed in order to ensure the adequate provision of salaries for these healthcare workers. ${ }^{55}$ Furthermore, a human resource programme supplementing SUS's work in the area of diabetes treatment was also eliminated. The aforementioned Mais Médicos programme, vital for delivering diabetic medication and care (particularly in hard to reach rural areas), was immediately shut down shortly after Bolsonaro entered office; the primary reason for this was due to Bolsonaro's commitment to securing the employment and expansion of SUS workers in Brazil. But as mentioned shortly, this decision also reflected the administration's alternative foreign policy objectives.

President Bolsonaro's commitment to reducing the government's role in public health has also contributed to a decline in access to diabetic medicine. In July 2019, for example, under the Bolsonaro administration the $\mathrm{MoH}$ to cancel its partnership with seven publicly funded pharmaceutical industries, such as Biomanguinhos, Butantâ, Bahiafarma, Farmanguinhos, Furp and Tecpar, which produce several medications treating not only type 2 diabetes, but also other types of cancer. ${ }^{56}$ These public partnerships were critical for supplying medications for SUS, through the aforementioned Aque Tem Farmácia programme. ${ }^{56}$ Not only do the elimination of these contracts obstruct the operations of these public sector industries, but in the future, it will cost more money for the government to obtain these drugs from the private sector. ${ }^{56}$ Furthermore, the Aque Tem Farmácia programme has not been able to ensure adequate financial support for the purchase of medications from the $\mathrm{MoH}$, in turn leaving thousands of government-ensured SUS patients without access to drugs. This has been especially problematic for elderly patients that are in need of specialised, more expensive 
medications. ${ }^{57}$ In this situation, the number of diabetics having to spend out-of-pocket for medications has increased. ${ }^{57}$

What's more, the ongoing decrease in the $\mathrm{MoH}$ budget for the Farmácia Popular programme has led to the shutdown of approximately 400 public pharmacies participating in the programme. ${ }^{58}$ To make matters worse, recently there has been no federal director in charge of the Farmácia Popular programme, resulting in a lack of managerial direction and vision. ${ }^{58}$ The closing of these public pharmacies has further contributed to a decline in accessibility of diabetes medications, especially in poor areas. ${ }^{58}$

But why did this institutional and policy reversal occur? First, unlike Dilma, under the Temer administration, the government had no geopolitical or domestic electoral incentives to sustain the previous administration's policy reforms. The glory years of Brazilian international cooperation in health, though some argue began to decline under Dilma, essentially came to an abrupt end under the Temer administration, affecting international cooperation and solidarity with other nations. ${ }^{59}$ In large part, this had to do with Temer and the MDB political party's geopolitical isolation, proclaiming a new mandate to focus on Brazil's domestic economic and political challenges instead of foreign policy matters. Unlike Dilma, Temer's goal was to first establish Brazil's international reputation as a government committed to economic stability and recovery, rather than projecting itself as an emerging power. ${ }^{60}$ Moreover, Temer believed that it was imperative to emphasise the government's political stability and economic recovery from the previous Lula and Dilma administrations. With respect to foreign policy, the only area that Temer emphasised was on increasing Brazil's trade relations with the USA, Europe and China, and Brazil's ascension into the OECD. ${ }^{60}{ }^{61}$ Unlike Lula and Dilma, Temer was not focused on increasing Brazil's influence within the UN, such as through the UN Security Council and other UN bodies. ${ }^{61}$ Thus, it was economic motive, not political, that shaped Temer's stance towards the world. For unlike the presidents before him, in the area of foreign policy, Temer's focus was not on global health cooperation. ${ }^{62}$

This disengagement from the international community persisted under the Bolsonaro administration (2019present), expanding to other social welfare policy areas, such as the environment. ${ }^{63}$ Analysts claim that Bolsonaro has undermined the government's historic track record in participating in constructive international diplomacy. ${ }^{64}$ Soon after entering office, prominent former diplomatic officials accused Bolsonaro of undermining the government's historic commitment to working with the international community, especially in the areas of climate change. ${ }^{64}$ In addition to adopting a more isolationist tone, shying away from closer international and regional cooperation, Bolsonaro strengthened his ties with the USA President Donad Trump, and has disrupted relations with Brazil's dominant trade partner, China. ${ }^{64}$
In addition, beginning with the Temer administration, presidential interests in making access to type 2 diabetesor any public health services-an electoral matter never emerged. This mainly had to do with the new conservative government's lack of interest in supporting Lula, Dilma and the PT party's stance on viewing access to diabetic medicine (and medicines in general) as a necessity to avoid growing out-of-pocket expenses and health-related poverty. At the same time, the Temer administration claimed that excessive state spending for antipoverty measures, such as Bolsa Família, was to blame for Brazil's ongoing fiscal deficits and poor economic performance. Temer and Bolsonaro's governments in fact vehemently campaigned against increasing anti-poverty spending.

In this context, there are no longer any geopolitical or domestic electoral incentives to continue supporting funding for much needed type 2 diabetic treatment and self-care management services. And this has occurred at a time when then number of patients with type 2 diabetes and their ongoing healthcare needs continue to burgeon. Unless the Bolsonaro administration changes course and begins to support these programmes, not only will diabetesrelated deaths increase, but they will inevitably cost Brazil's healthcare system an excessive amount of money.

\section{DISCUSSION}

This study has revealed that international and domestic political factors play an important role in explaining the evolution of type 2 diabetes policy in Brazil. This is a new area of scholarly research, as most of the recent work discussing type 2 diabetes policy has focused on health systems, capacity building and implementation. However, to date, we know little about why and how a nations' foreign policy aspirations and presidential electoral incentives intertwine to affect both the universal provision of type 2 diabetic medication and primary care reform.

As we saw in Brazil, under the Lula and Dilma presidential administrations, government aspirations to establish its reputation as an internationally recognised leader in type 2 diabetes policy by sharing successful policy lessons at international forums and making policy recommendations generated a strong domestic commitment to ensuring the universal provision of diabetic medicine and primary care innovations. These policy reforms were therefore the means through which the Lula and Dilma administration achieved their foreign policy aspirations. At the same time, these aspirations merged with these presidents' usage of the universal distribution of diabetes medication as an electoral strategy. Under the Lula and Dilma administrations, high out-of-pocket spending for type 2 diabetes medication was viewed as a contributing factor to poverty; this, in turn, provided a unique opportunity to reconceptualise diabetes treatment through an antipoverty discourse and electoral strategy. In contrast, the more politically conservative Temer and Bolsonaro administration's reluctance to engage in global health diplomacy and apathy towards politicising diabetes treatment generated essentially no incentives to support 
the previous administration's policy endeavours. In this context, fewer type 2 diabetics have had access to treatment services, while the rate of diabetes continues to increase and impose greater costs for individuals and the healthcare sector.

Of course, one could argue that Brazil's shift in type 2 diabetes policy had more to do with worsening economic conditions and the increased unavailability of federal funding from the MoH. This fiscal argument does not hold, however, as both the Lula and Dilma administration were also operating within an economic recession, with congressional funding for the $\mathrm{MoH}$ flat-lining under Lula and decreasing under Dilma. This further highlights the unique political attention that type 2 diabetes and other related NCDs, such as obesity and hypertension, received under Lula and Dilma, given their high prevalence rate among the poor. Future research in Brazil and other developing nations would therefore benefit from comparing government funding for particular public health programmes, their association with different socioeconomic classes, in a context of economic recession in order to reveal the deeper international and domestic political factors explaining why some public health programmes are prioritised over others.

Yet another key point to raise is the association between democratic regime type and foreign policy aspirations in public health. One could easily argue that Brazil's recent policy challenges has to do with the arrival of a more conservative government that is apathetic towards bolstering its foreign policies in health. However, this argument fails to account for several of Brazil's previously conservative democratic governments and their commitment to global health diplomacy, such as the politically conservative administrations throughout the 19th century and arguably even under the more recent Fernando H. Cardoso administration. ${ }^{13}$ Thus, one should not simply relegate Brazil's recent diabetes policy failures and institutional challenges to the presence of a more conservative democratic political regimen.

There were, however, several limitations with this study. First, the analysis could have extended further back in time to assess the political factors shaping type 2 diabetes policy, both at the national and especially, the subnational level. Within Brazil's decentralised governance structure, several states and municipalities have been innovators in NCD policy, especially in the area of obesity and type 2 diabetes prevention. Second, this study could have benefited from in-depth interviews with key politicians, bureaucrats and international health agencies to further ascertain the political rationale behind supporting type 2 diabetes policies. Finally, Brazil could have been compared with other similar emerging economies, such as Mexico, Chile and Argentina, that are also experiencing a surge in type 2 diabetes cases. Future work could engage in this kind of comparison in order to confirm if the dovetailing of a nation's foreign policy aspirations in health and electoral incentives leads to improvements in type 2 diabetes policies and their implementation.

\section{CONCLUSION}

This study has argued that better understanding the evolution of type 2 diabetes policies and primary care institutional reform may benefit from an analysis of the international and domestic political factors compelling politicians to deepen reform efforts, and how a change in these political conditions can undermine previous reform efforts. This approach provides deeper insights into why governments experience changes in their political interests, incentives and commitment to reducing the prevalence of type 2 diabetes while helping patients successfully manage their condition. To better understand this process, future work may benefit from comparing Brazil to other emerging economies that are experiencing a similar increase in growth trajectory in type 2 diabetic cases, such as Mexico, India, Indonesia, South Africa and China.

Twitter Eduardo J Gómez @Eduardo_J_Gomez

Contributors EG is the sole author and wrote all of this research manuscript.

Funding The authors have not declared a specific grant for this research from any funding agency in the public, commercial or not-for-profit sectors.

Competing interests None declared.

Patient and public involvement Patients and/or the public were not involved in the design, or conduct, or reporting, or dissemination plans of this research.

Patient consent for publication Not required.

Provenance and peer review Not commissioned; externally peer reviewed.

Data availability statement Data are available in a public, open access repository. Data are available on request. All data provided in this article are available on request from the main author.

Open access This is an open access article distributed in accordance with the Creative Commons Attribution Non Commercial (CC BY-NC 4.0) license, which permits others to distribute, remix, adapt, build upon this work non-commercially, and license their derivative works on different terms, provided the original work is properly cited, appropriate credit is given, any changes made indicated, and the use is non-commercial. See: http://creativecommons.org/licenses/by-nc/4.0/.

\section{REFERENCES}

1 Coutinho WF, Silva Júnior WS, Wellington SSJ. Diabetes care in Brazil. Ann Glob Health 2015;81:735-41.

2 Pimentel I. Taxa de incidência de diabetes cresceu $61.8 \%$ nos últimos 10 anos. Fiocruz, 2019. Available: https://portal.fiocruz.br/ noticia/taxa-de-incidencia-de-diabetes-cresceu-618-nos-ultimos10-anos [Accessed 31 Aug 2019].

3 Sociedade Brasileira de Diabetes. Posicionamento Oficial SBD No. 01/2019. Conducta a Terapêutica no Diabetes Tipo 2: Algoritmo SBD. São Paulo: Sociedade Brasileira de Diabetes, 2019.

4 Sociedade Brasileira de Diabetes. Qual a situação de diabetes no Brasil? E o custo da insulina? Noticias, 2018 [Accessed 31 Aug 2019].

5 Colagiuri S, Kent J, Kanu T, et al. Rising to the challenge: preventing and managing type 2 diabetes. Report of the WISH Diabetes Forum, 2015.

6 Arredondo A. Type 2 diabetes and health care costs in Latin America: exploring the need for greater preventive medicine. BMC Med 2014;12:136.

7 Spann SJ, Nutting PA, Galliher JM, et al. Management of type 2 diabetes in the primary care setting: a practice-based research network study. Ann Fam Med 2006;4:23-31.

8 Huang M, Zhao R, Li S, et al. Self-Management behavior in patients with type 2 diabetes: a cross-sectional survey in Western urban China. PLoS One 2014;9:e95138.

9 Balabanova D, McKee M, Koroleva N, et al. Navigating the health system: diabetes care in Georgia. Health Policy Plan 2009;24:46-54.

10 Takian A, Kazempour-Ardebili S. Diabetes dictating policy: an editorial Commemorating World health day 2016. Int J Health Policy Manag 2016;5:571-3. 
11 Agudelo-Suárez AA, Ruiz-Cantero MT, González-Zapata LI, et al. The parliamentary political agenda: a tool for policy analysis of diabetes priorities in Spain. Gac Sanit 2012;26:554-9.

12 Mayes R, Armistead B, Blair A. Chronic disease, prevention policy, and the future of public health and primary care. Med Health Care Philos 2013;16:691-7.

13 Gómez E. Geopolitics in health: confronting obesity, AIDS, and tuberculosis in the emerging BRICS economies. Baltimore: Johns Hopkins University Press, 2018.

14 Ruger JP. Democracy and health. QJM 2005;98:299-304.

15 Carbone G. Democratic demands and social policies: the politics of health reform in Ghana. J Mod Afr Stud 2011;49:381-408.

16 Gayard N. Health as niche diplomacy: assessing design and practices of Brazilian health diplomacy at the beginning of the $21^{\text {st }}$ century. Revista Brasileira de Política Internacional 2019;62:1-19.

17 Feldbaum H, Michaud J. Health diplomacy and the enduring relevance of foreign policy interests. PLoS Med 2010;7:e1000226.

18 Gerring J. What is a case study and what is it good for? Am Polit Sci Rev 2004;98:341-54.

19 Bergman M, Buysschaert M, Schwarz PE, et al. Diabetes prevention: global health policy and perspectives from the ground. Diabetes Manag 2012;2:309-21.

20 Gómez EJ. Political Party ambitions and type-2 diabetes policy in Brazil and Mexico.. Health Economics, Policy and Law 2018;15.

21 Beran D, Ewen M, Laing R. Constraints and challenges in access to insulin: a global perspective. Lancet Diabetes Endocrinol 2016;4:275-85.

22 Narayan KMV, Echouffo-Tcheugui JB, Mohan V, et al. Global prevention and control of type 2 diabetes will require paradigm shifts in policies within and among countries. Health Aff 2012;31:84-92.

23 Penn ML, Kennedy AP, Vassilev II, et al. Modelling self-management pathways for people with diabetes in primary care. BMC Fam Pract 2015;16:112.

24 Zgibor JC, Songer TJ. External barriers to diabetes care: addressing personal and health systems issues. Diabetes Spectrum 2001;14:23-8.

25 Hall G. Supporting successful self-management in diabetes. Diabetes \& Primary Care 2015;17:94-101.

26 Khunti K, Gray LJ, Skinner T, et al. Effectiveness of a diabetes education and self management programme (DESMOND) for people with newly diagnosed type 2 diabetes mellitus: three year followup of a cluster randomised controlled trial in primary care. BMJ 2012;344:e2333

27 Dube L, Van den Broucke S, Dhoore W, et al. An audit of diabetes self-management education programs in South Africa. $J$ Public Health Res 2015;4:1--10.

28 Stellefson M, Dipnarine K, Stopka C. The chronic care model and diabetes management in US primary care settings: a systematic review. Prev Chronic Dis 2013;10:120180.

29 Tai T-Y, Chuang L-M, Tsai S-T, et al. Treatment of type 2 diabetes mellitus in a primary care setting in Taiwan: comparison with secondary/tertiary care. J Formos Med Assoc 2006;105:105-17.

30 Erny-Albrecht PB, Oliver-Baxter J. The role of primary health care in primary and secondary prevention of diabetes. In: Policy issue review. PHCRIS: Primary Health Care Research \& Information Service, 2015

31 Ansari R, Dixon J, Coles J. Type 2 diabetes: challenges to health care system of Pakistan. Int J Diabetes Res 2015;4:7-12.

32 Weaver RR, Lemonde M, Payman N, et al. Health capabilities and diabetes self-management: the impact of economic, social, and cultural resources. Soc Sci Med 2014;102:58-68.

33 Sabatier P, ed. Theories of the policy process. Westview Press, 2007.

34 Mahoney J, Thelen K, eds. Explaining institutional change: ambiguity, agency, and power. New York: Cambridge University Press, 2010.

35 Oliver TR. The politics of public health policy. Annu Rev Public Health 2006;27:195-233.

36 Alencar TdeOS, Araújo PS, Costa EA, et al. Programa Farmácia popular do Brasil: uma análise política de sua origem, seus desdobramentos E inflexões. Saúde em Debate 2018:42:159-72.

37 Gómez EJ. Political Party ambitions and type-2 diabetes policy in Brazil and Mexico. Health Econ Policy Law 2020;15:261-76.

38 Leitão T. Dilma: Programa saúde não tem preço beneficiou mas de 16 milhões pessoas. Agência Brasil, 2013 [Accessed 2 Jan 2020].

39 Bertoldi AD, Kanavos P, França GVA, et al. Epidemiology, management, complications and costs associated with type 2 diabetes in Brazil: a comprehensive literature review. Global Health 2013;9:62.

40 Gómez EJ. Understanding the United States and Brazil's response to obesity: institutional conversion, policy reform, and the lessons learned. Global Health 2015;11:1-14.

41 Globo O. Videos de sete países, 644 médicos estão no Brasil para atuar no interior. Edição do Dia, 2013 [Accessed 2 Jan 2020].

42 Lefébvre P. The diabetes Summit for Latin America, Bahia, Brazil. A report. World Diabetes Foundation, 2010.

43 Mendes da Silva R, Caetano R. Farmácia popular do Brasil program: characterization and evolution between 2004 and 2012. Ciência \& Saúde Coletiva 2015;20:2943-56.

44 Jurberg C. Flawed but fair: Brazil's health system reaches out to the poor. Bull World Health Organ 2008;86:248-9.

45 Stein AT, Ferri CP. Innovation and achievement for primary care in Brazil: new challenges. BJGP Open 2017;1:BJGP-2017-0857.

46 do Valle Nascimento TMR, Resnicow K, Nery M, et al. A pilot study of a community health Agent-led type 2 diabetes self-management program using motivational Interviewing-based approaches in a public primary care center in São Paulo, Brazil. BMC Health Serv Res 2017;17:1-10.

47 Fitzgerald J. Brazil; the MAIS medicos programme. Geneva: World Health Oranization, 2018.

48 PAHO. PAHO/WHO and governments of Brazil and Cuba renew "Maise Medicos" program. PAHO News. Available: https://www. paho.org/hq/index.php?option=com content\&view=article\&id= 12525:ops-gobiernos-brasil-cuba-oficializan-renovacion-programamais-medicos\&ltemid $=42099 \&$ lang $=e n$ [Accessed 26 Apr 2020].

49 WHO. Helping people with diabetes manage their health and lives in Brazil. The World Health Organization press, 2016.

50 Valor. Insulin produzida no Brasil será vendida a preços baixos, diz Dilma. O Globo on-line news, 2013. Available: g1.globo.com/ economia/noticia/2013/04/insulina-produzida-no-brasil-seravendida-a- precos-baixos-diz-dilma.html [Accessed 7 Jan 2020].

51 Cristaldo H. Dilma vai a Belo Horizonte para anúncio de fábrica de insulina. EBC news Brasil 2013.

52 Saldiva PHN, Veras M. Gastos públicos com saúde: breve histórico, situação atual e perspectivas futuras. Estudos Advançados 2018;32.

53 Spagnuolo S. Governo reduz em 20\% rede de farmácias populares no Brasil. AF News, 2017 [Accessed 21 Dec 2019].

54 Formenti L. Ministério da Saúde estuda retirar insulina do program Farmácia Popular. UOL News, 2017 [Accessed 21 Dec 2019].

55 Júnior J. Governo sugere reformulação do Farmácia Popular para pagar reajuste de agentes comunitários. Câmara dos Deputados, 2018 [Accessed 21 Dec 2019].

56 Moura T. Ministério da Saúde suspende 19 medicamentos gratuitos do SUS. Correio Braziliense. Available: https://www. correiobraziliense.com.br/app/noticia/ciencia-e- saude/2019/07/16/ interna_ciencia_saude,771353/ministerio-da-saude-suspende-19medicamentos-gratuitos-do-sus.shtml [Accessed 31 Aug 2019].

57 Gómez EJ. Brazil's health system suffers as recession bites. BBC, 2016. Available: https://www.bbc.com/news/world-latin-america36388521 [Accessed 9 Mar 2020].

58 Junqueira D. Com menos recursos e sem coordinador, Farmácia Popular deixa de atender 7 milhões em 2 anos. Repórter Brasil, 2019 [Accessed 21 Dec 2019].

59 Buss PM. Brazilian international cooperation in health in the era of Sus. Cien Saude Colet 2018;23:1881-1890.

60 Costa Silva AV. A política externa do governo Michel Temer (2016-2018): mudanças para a legitimidade? um teste da teoria de Charles Hermann. Conjuntura Austral: Journal of the Global South 2019;10:23-41.

61 Oliveira C. A política externa do governo Temer: características e oportunidades de USA política pública negligenciada. FRoNteiRA 2018;17:296-309.

62 Fernandes J. O Brasil e a saúde pública Internacional: Uma análise das conexões entre o doméstico e o Internacional. $6^{\circ}$ Encontro Nacional da ABRI Estudos sobre História das Relações Internacionais e da Política Externa; July 25-28, Belo Horizonte, Brazil, 2017.

63 Lissardy G. Jair Bolsonaro: Cómo cambió la relación de Brasil con el resto de América Latina tras 6 meses como president. BBC, 2019.

64 Phillips T. Diplomáticos Brasileños denuncian que Bolsonaro está dinamitando décadad de política exterior. Eldiario.es [Accessed 22 Dec 2019]. 